\title{
William, an Englishman (1919) and the Collapse of Cicely Hamilton's Pre-war Meliorism
}

\section{Luísa Flora}

\begin{abstract}
William, an Englishman is a novel written in a tent near the French front by a 'non-combatant': the wartime volunteer nurse, postal overseer and theatrical performer Cicely Hamilton. A well-known playwright, actress, suffrage militant, polemical essayist before the conflict, Hamilton, nowadays largely overlooked, performed here a post-mortem exploration of some influential attitudes which were transformed by the experience of war. Coming from someone who had been particularly active on the British radical scene, the text's denunciation of social progress, pacifism, internationalism, and even votes for women as naive ideals may appear unexpected. She drew from long personal knowledge as well as contemporary documentation to write a novel that, while not untouched by sympathy for her characters, is often brutal. The collapse of Hamilton's previous political optimism, her (self-ironical) criticism of any belief in the perfectibility of human beings may come as a shock even today. But those familiar with Senlis (1917) might have anticipated Hamilton's sombre 1919 text. 'Modern warfare is so monstrous, all-engrossing and complex, that there is a sense, and a very real sense, in which hardly a civilian stands outside it; where the strife is to the death with an equal opponent the non-combatant ceases to exist.' The abuse and strategic bombing of civilian populations, the collapse of former distinctions between combatants and non-combatants, the mobilization of almost entire nations were early on denounced by the writer. 'No modern nation could fight for its life with its men in uniform only; it must mobilize, nominally or not, every class of its population for a struggle, too great and too deadly for the combatant to carry alone.' (Senlis 34) Her discerning eye read the Great War for what it was: a conflict which was leaving no domain of social, economic and political life unsullied, a total war.
\end{abstract}

L. Flora $(\bowtie)$

University of Lisbon and ULICES (University of Lisbon Centre for English Studies),

Lisbon, Portugal

e-mail: luisa.flora@gmail.com

(C) Springer International Publishing AG 2018

A. Barker et al. (eds.), Personal Narratives, Peripheral Theatres:

Essays on the Great War (1914-18), Issues in Literature and Culture,

DOI 10.1007/978-3-319-66851-2_9 
No war, I suppose, save this, has seen what you then might see nightly: the regular desertion and emptying of a city, its abandonment as dusk came down. In the old wars men fled into walled towns for refuge from their enemy; in our wars, the wall, when the night comes down, is a trap that you fly from to the open. (Hamilton, 1918, 577)

The catastrophic menace Cicely Hamilton (1872-1952) identifies in 'Bombarded', an essay published in October 1918 in The North American Review, the new experience of being exposed to air raids, will have a significant dimension at the end of William, an Englishman, her then soon to be published novel. German nightly raids that targeted civilians as much as military goals, one until recently inconceivable reality, were as she later wrote in Life Errant, her autobiography, 'a promise of terror to come'.

I remembered thinking, as I passed the blank houses, that here was a phenomenon unknown to the wars whereof history tells us. In the old wars men sheltered behind walls and found safety in numbers (...) and in walls. But in our wars, the wars of the air and the laboratory, the wall, like enough, is a trap that you fly from to the open, and there is danger, not safety, in numbers - the crowd is a target to the terror that strikes from above. All the country, nightly, was alive with men and women who, in obedience to the principles of the new warfare, had fled from the neighbourhood of the target - the town - and scattered in small groups that they might be ignored and invisible. (...) And this, one realised, was only the beginning of air-power and the need for invisibility that air-power imposes; what we saw was but a promise of terror to come, a foreshadowing of full-grown achievement. Lying on the hillside one glimpsed something, at least, of the chaos of full-grown achievement. The chaos of a people (...) driven out of its towns and kept out of them; (...) kept on the run; driven hither and thither, reduced to starvation and savagery. (Hamilton, 1935, 148-149)

In Senlis, her 1917 homage to a French 'mutilated' city 'ravaged by the German' (Hamilton, 1917a, b, 1), Hamilton had already deplored the strategic bombardment of civilian populations, the collapse of former distinctions between combatants and non-combatants, the mobilisation of almost entire nations.

Modern warfare is so monstrous, all-engrossing and complex, that there is a sense, and a very real sense, in which hardly a civilian stands outside it; where the strife is to the death with an equal opponent the non-combatant ceases to exist. No modern nation could fight for its life with its men in uniform only; it must mobilize, nominally or not, every class of its population for a struggle too great and too deadly for the combatant to carry on alone. (Hamilton, 1917a, b, 34)

Cicely Hamilton was reading the Great War for what it was: a conflict which was leaving no domain of social, economic and political life unsullied, a total war. William, an Englishman marks a major transition in her work. Before the war the writer had been essentially devoted to feminist and suffrage issues. During and after the war, in light of the impact and widespread devastation brought by the conflict, she was particularly aware of the real threat the use of the new military technologies, especially chemical weapons and aerial bombardment, presented to each and everyone.

The war as traumatic event, and the crisis of public and private experience it enormously intensified, encouraged Hamilton to share her own considerable knowledge of the conflict and respond through writing to the physical and 
emotional horror she witnessed. Her personal engagement with the conflict produced contemporary reconstructions of that horror in Senlis as well as 'Bombarded' and in William, an Englishman, her war novel.

Looking back on her long experience of the war in France, Hamilton wrote in 1935:

When you have once accepted the more than possibility that your civilisation is heading for destruction, it is almost inevitable that you will slip into indifference towards many ideas and interests and activities that would otherwise have seemed to you important. That at least has been the case with me; I find it impossible to take any real interest in long-distance political 'planning' of any sort or kind, (...). Unless we can master the air-menace, the city, as we know it, is bound to go; on the day the first aeroplane rose from the ground the foundations of every city in the world were shaken. (Hamilton, 1935, 151-152)

While it did not destroy some of her deepest convictions, namely her stand on women's civil, political, sexual and reproductive rights, her first-hand knowledge of the realities of war, beyond anything she could have imagined, did change her priorities. '[D]uring the interwar years, Hamilton's creative writing no longer took its inspiration from women's rights because the war had redirected her imagination to the menace of human aggressiveness.' (Blodgett, 1990, 104) The writer would then devote particular attention to the threat of the new technologies as her 1922 pessimistic novel, Theodore Savage, makes clear (Hamilton, 1922). ${ }^{1}$

Hamilton did not actually 'slip into indifference'. She was as active as she had been before the conflict, but her writing reflects a transformed perspective. Contrasting the experience of the violence endured by soldiers and non-combatants with her previously untested beliefs and the struggle for the vote in the years leading up to war, Hamilton soon criticized her own long-cherished illusions on the possibilities for human progress and improvement. As both Senlis and 'Bombarded' expose, during the war the writer was intent on showing how the conflict was affecting everyone. In 'Non-Combatant' (1917) she denounced the anguish imposed on all those who were coerced to remain passive.

Before one drop of angry blood was shed

I was sore hurt and beaten to my knee;

Before one fighting man reeled back and died

The War-Lords struck at me.

They struck me down an idle, useless mouth,

As cumbrous, nay, more cumbrous than the dead,

\footnotetext{
${ }^{1}$ Cicely Hamilton, Theodore Savage: A Story of the Past or the Future, London: Leonard Parsons, 1922, reissued with minor changes by Jonathan Cape in 1928 in Britain and the United States under the title Lest Ye Die.

See Martin Hermann, A History of Fear: British Apocalyptic Fiction, 1895-2011, foreword by Adam Roberts, Berlin, epubli, 2015.

See also Paul K. Saint-Amour, Tense Future: Modernism, Total War, Encyclopaedic Form, Oxford: Oxford University Press, 2015. Kindle edition.
} 
With life and heart afire to give and give

I take a dole instead.

With life and heart afire to give and give

I take and eat the bread of charity.

In all the length of all eager land,

No man has need of me.

That is my hurt my burning, beating wound;

That is the spear-thrust driven through my pride!

With aimless hands, and mouth that must be fed,

I wait and stand aside.

Let me endure it, then, with stiffened lip:

I, even I, have suffered in the strife!

Let me endure it then I give my pride

Where others give a life. ${ }^{2}$

Deploring the abyss driven by those in power between people on the frontline and those who were left at home, Hamilton does not distinguish between women and men. Though the sense of not being able to fully contribute to the war effort was, due to government and military restrictions on female intervention, perhaps more common in women, limiting most of them to allegedly feminine war work, such frustration will be shared by her 1919 male protagonist. ${ }^{3}$

When the most exalted form of hegemonic wartime masculinity is military masculinity (...) and femininity is defined by domestic vulnerability, when the war dead are construed as male and the mourners of the war dead as female, representations of both genders are distorted: how to accommodate the civilian male, the military male excluded from combat or women serving in uniform? (Peniston-Bird \& Ugolini, 2015, 3)

Following his traumatic experience as a civilian in Belgium, William, a former pacifist, feels useless until his diminutive contribution to the war effort is accepted, and even after that.

Before the war, dealing with a hostile reality, Hamilton had been deeply invested in the belief that through effort and struggle the world would become a better place.

${ }^{2}$ www.inspirationalstories.com/poems/non-combatant/cicely-hamilton-poems Accessed 26.09. 2015.

For other contemporary perspectives see Rose Macaulay's Non-Combatants and Others. Alix Sandomir, the protagonist, muses: 'Fighting war. I suppose really it's the only thing non-combatants can do with war, to make it hurt them less...as they can't go...' London: Methuen, 1986 (1916), 173.

See also May Sinclair, A Journal of Impressions in Belgium (1915, New York: The Macmillan Company, 1915. https://www.gutenberg.org/files/31332/31332-h/31332-h.htm Accessed 07.03. 2016.

${ }^{3}$ See Claire Buck, 'British Women's Writing of the Great War', 2005. 
Her late-Victorian and early twentieth-century meliorism was brutally challenged by the shock and trauma of war, her former confidence on uninterrupted civilizational ascent forced to confront its brittle foundations. ${ }^{4}$ The war powerfully disrupted the former optimistic narrative of human liberation.

\begin{abstract}
Looking through the chaos before her as if it were a scrim, Hamilton sees beyond it a future in which the terror of a mature air power would, she imagined, turn town-dwelling citizens into starving, barbarous nomads. (...) [Her] loss of the Enlightenment narrative appears to happen, in part, because the terror of air power annihilates the continuity of past, present, and future on which such a narrative depends. (Saint-Amour, 2015, Loc. 3607-3614)
\end{abstract}

Reflecting upon her own prolonged experience near the front, she realized that human progress was not inevitable, re-evaluated some of her most authentic ideals, and reappraised the human potential for self-destruction.

William, an Englishman, published in 1919, was an immediate enormous success and received in 1920 the first Femina award. ${ }^{5}$ Long neglected and out of print, the novel was in 1999 chosen to launch Persephone's reading list. ${ }^{6}$ This chapter is a modest contribution to read the novel and help redress what has been characterized as 'Hamilton's erasure from history.,"7

Often referred to as a suffrage novel, William, an Englishman should perhaps be considered as a novel whose main characters, inexperienced young people engaged before the war in the struggle for the vote, come to realize too late that the world is more complex than their pre-war militancy had prepared them for. In 1935, the author recalled the genesis of the book:

(...) my novel, (...), was taken by its public and critics for a war novel, but as a matter of fact it was only accidentally that it dealt with the catastrophe of 1914. It was really a 'suffrage' novel; its outline had taken shape in my thoughts before there was any suspicion of the war to come, and its beginnings I date from a gathering where I heard certain

\footnotetext{
${ }^{4}$ Meliorism, The doctrine, intermediate between optimism and pessimism, which affirms that the world may be made better by rightly-directed human effort. James Sully (Pessimism, 1877) attributed the term to George Eliot, "the faith which affirms not merely our power of lessening evil - this nobody questions - but also our ability to increase the amount of positive good." OED.

See also James Sully, Pessimism: A History and A Criticism, Henry S. King \& Co., 1877, Chapter XIV, 399-401. https://archive.org/details/pessimismahisto01sullgoog. Accessed 26.01. 2016.

${ }^{5}$ And first English prize-winner of the then most prominent prize to be awarded to any woman writer. See Prix Femina. http://discovery.nationalarchives.gov.uk/details/rd/a77f8754-6b14-448ca06f-a491a43387f5. Accessed 27.09.2015.

${ }^{6}$ Cicely Hamilton, William, an Englishman, London: Persephone Books, 1999 (1919). All references to the novel will be to this edition (first published in London by Skeffington \& Son).

See also Urmilla Seshagiri, 'Making It New: Persephone Books and the Modernist Project', Modern Fiction Studies Volume 59, Number 2, Summer 2013, pp. 241-287, particularly 260-261. ${ }^{7}$ Margaret D. Stetz, Review of The Life And Rebellious Times Of Cicely Hamilton: Actress, Writer, Suffragist, by Lis Whitelaw, Tulsa Women's Studies in Women's Literature, Vol. 10, No. 2, (Autumn, 1991), 307.

Several of her works, including Life Errant and the 1940 Lament for Democracy, have long been out-of-print.
} 
members of the militant section hold forth on the subject of their 'war'. (...) I had no more understanding than the average civilian of what warfare under modern conditions would mean; but I did understand that it meant something more dangerous (..) than rough-and-tumbles round the Houses of Parliament; (...) here was material for a story; a young man and woman, enthusiastic, ignorant, who had thought of their little political scuffle as war and who stumbled accidentally into the other kind of war - of bullets and blood and high explosives. (Hamilton, 1935, 84-85)

The project was interrupted by the war and nearly forgotten until Hamilton returned to it in 'the form of a war novel' (Hamilton, 1935, 85).

Interpreting the book within the context of the struggle between suffragists and suffragettes, Claire Tylee goes a long way to persuade her readers that it is in fact anti-suffrage. ${ }^{8}$ It is not. There is a wide difference between denouncing some militants' fanatical zeal and writing against the expansion of suffrage. However, the author's main concern throughout her life was the struggle for women's rights not suffrage per se. ${ }^{9}$

(...) if I worked for women's enfranchisement (and I did work quite hard) it wasn't because I hoped great things from counting female noses at general elections, but because the agitation for women's enfranchisement must inevitably shake and weaken the tradition of the 'normal woman'. The 'normal woman' with her 'destiny' of marriage and motherhood and housekeeping, and no interest outside her home - and especially no interest in the man's preserve of politics! My personal revolt was feminist rather than suffragist; (...). (Hamilton, 1935, 65)

Cicely Hamilton lived to be eighty. She never renounced her feminist principles. She most certainly did not value the right to vote as the ultimate panacea to all problems and the 1st World War undeniably transformed some earlier illusions.

What use was the vote as a weapon against German guns, submarines and Gothas? The problem of the moment was to keep ourselves alive, and when a people is engaged in a life-and-death struggle, it is apt to lose interest in matters which yesterday were of sufficient importance to raise it to a fury of dispute....I remember - how well I remember - receiving official intimation that my name had been placed on the register of the Chelsea electorate! I was in Abbeville at the time, and, as the post arrived, a battery of Archies, somewhere on the hill, began to thud; an enemy aeroplane was over, taking photographs. I remember thinking, as I read the notice, of all that the suffrage had meant for us, a year or two before! How we had marched for the suffrage and held meetings and been shouted at; and how friends of mine, filled with the spirit of the martyr, had hurled themselves at policemen and broken windows - and starved themselves in prison: and that now, at this moment of achieved enfranchisement, what really interested me was not the thought of voting at the next election, but the puffs of smoke that the Archies sent after the escaping plane. Truth to tell, at that moment I didn't care a button for my vote; and rightly or wrongly, I have always imagined that the Government gave it me in much the same mood as I received it. (Hamilton, 1935, 67-68) $)^{10}$

${ }^{8}$ See Tylee $(1990,133-141)$.

${ }^{9}$ See Life Errant, 'Women on the Warpath' et passim. See Whitelaw (1990). See also Noveck (2015).

${ }^{10}$ See also Whitelaw, particularly Chapter Ten, 'Equality First', 179-204. 
William, an Englishman is also a war novel, though not exactly in the sense of being written from the perspective of a soldier, or even a nurse or someone suffering on the home front. ${ }^{11}$ A truth-telling narrative of the war, it reveals the distance between pre-war illusions and post-war disappointment. Such frustration is indisputably shared by both author and characters.

Prior to the conflict, Hamilton had been a well-known playwright, actress, stage director, suffrage militant, polemical essayist and committed internationalist. ${ }^{12}$ Her by then published production included four full-length plays, two one acts, two novels, Marriage as a Trade (1909), numerous articles, pamphlets, speeches. For some time a member of the Women's Social and Political Union, ${ }^{13}$ she left dissatisfied with Mrs. Pankhurst's autocratic leadership and became a founder of the Actresses' Franchise League and of the Women Writers Suffrage League.

Extremely active on the British radical scene, Hamilton's plays Diana of Dobsons (1908), How the Vote Was Won (1909) or A Pageant of Great Women (1910) obtained enormous success and helped, as they were meant to, attract audiences to the suffragist cause. ${ }^{14}$

Her important feminist treatise, Marriage as a Trade, an immediately influential book and a classic nowadays still in print, examines the condition of women, arguing for education and training that would release them from having to rely on the marriage market for self-respect and financial support. One brief example of the essay's arguments reveals some of the issues later emphasized in Hamilton's autobiography.

If it be granted that marriage is (...) essentially a trade on the part of woman - the exchange of her person for the means of subsistence - it is legitimate to inquire into the manner in which that trade is carried on, and to compare the position of the worker in the matrimonial with the position of the worker in any other market. (...) the regulations governing compulsory service - the institution of slavery and the like - are always framed, not in the interests of the worker, but in the interests of those who impose his work upon him. The regulations governing exchange and barter in the marriage market, therefore, are necessarily framed in the interests of the employer - the male. (Hamilton, 1909, Loc. 330, p. 28) ${ }^{15}$

\footnotetext{
${ }^{11}$ 'If we ignore the devastation wreaked by war on women, children, civilians, animals, the land, buildings, bridges, communications, the entire fabric of family, social and civilized life, we can perhaps construe the makers of war to be its victims, but this requires that we imagine the world of war to be inhabited only by soldiers (...).' Hanley, 1991, 31.

Hanley was one of the first scholars to challenge Paul Fussell's selective myth of war literature in The Great War and Modern Memory, 1975.

${ }^{12}$ See Life Errant and Whitelaw's biography.

${ }^{13}$ She wrote the lyrics of Ethel Smyth's 1910 "The March of the Women" for the Women's Social and Political Union.

${ }^{14}$ How the Vote Was Won: A Play in One Act initially a story by Hamilton later dramatized with Christopher St John (alias Christabel Marshall).

${ }^{15}$ Marriage as A Trade's denunciation of marriage as the first degrading means of women earning a living preceded another reputed critique of patriarchy, Olive Schreiner's Woman and Labour (1911).
} 
In August 1914 Hamilton promptly decided to contribute to the war effort. ${ }^{16}$ She volunteered for one of the Scottish Women's Hospitals being prepared by Elsie Inglis. When the British War office turned down the offer of a hospital unit of one hundred beds entirely staffed by women, Dr Inglis offered her services to the French and the Serbian authorities; both readily accepted. From the end of November 1914 until May 1917, Hamilton was working for the Allies, in the Scottish Women's Hospital at the Abbey of Royaumont. ${ }^{17}$ Twenty five miles behind the trenches, she closely witnessed the suffering of both troops and civilians. She was involved in translation, letter writing, book-keeping, administration, nursing the wounded from the Battle of the Somme, organising concerts and plays for the soldiers. In the spring of 1917 she moved to Abbeville ${ }^{18}$ to produce "Concerts at the Front" until near the end of the war, returning in early 1919 to entertain the remaining troops.

In Abbeville Hamilton suffered a decisive shock:

(...) that night, as plane after plane came over from the east (...) above and beyond my personal fear was fear and horror of the future. For on that night there was born an idea which (...) I have never been able to get rid of; the idea (...) that if Science destroy our civilization, it will not be for the first time. (...) it was on the hill above Abbeville that the thought, in a flash, made havoc of my old beliefs in progress, and the onward march of humanity; I never knew till then how strong was my belief in progress, how completely I had taken the onward march for granted. (Hamilton, 1935, 149-151) ${ }^{19}$

Probably written in a tent near the French front in early 1918 and finished while on leave in England later that summer, William, an Englishman is a remarkably understated narrative of a young English couple, William Tully and Griselda Watkins, surprised in the Belgian countryside by the German invasion. ${ }^{20}$

The novel, told by a first-person omniscient narrator who sometimes goes into the protagonist's mind, relates the couple's appalling apprenticeship of moral and physical humiliation. While moved by genuine sympathy for her characters, Hamilton's text builds up on the narrator's (and the reader's) initial feeling of gentle

\footnotetext{
${ }^{16}$ Hamilton's reaction to the news of war was widely shared by most suffrage activists. Sylvia Pankhurst was of course the most famous exception to such widespread support.

${ }^{17}$ 'The progress and achievements of the hospital were followed with great interest by many of the leading women doctors (...) the reputation of women in the medical profession depended in part on their performance in difficult wartime conditions.' Crofton, 2013, Loc. 1177.

Hamilton has been considered a key figure in the whole enterprise.

${ }^{18} \mathrm{~A}$ major railway junction and important army base camp on the river Somme. See also Bowen (2010).

${ }^{19}$ The 'flash' originated her dystopian Theodore Savage. See note 1. See also Whitelaw, 173-178.

Saint-Amour characterizes Theodore Savage as: 'a speculative fiction whose description of a future air war followed by societal collapse realizes Hamilton's premonitions and epiphanies under the German bombs at Abbeville.' Loc. 3651.

The trauma of the bombardment touched 'her faith in a habitable future, her political agency, her investment in her life'. Ibidem, Loc. 3627.

${ }^{20}$ In February 1919, when William - an Englishman was first published, its forty-seven year old author was still in France, where she had been since the outbreak of the war (...).' Beauman, Preface to William, an Englishman, v.
} 
superiority towards them. On 21 June 1919, the anonymous reviewer for The Spectator wrote, 'the author at intervals relentlessly reminding the reader of the dates - May, June, and July, 1914. With the passing of every month the reader feels the tragedy of the World War drawing nearer and nearer. ${ }^{21}$

The novel's depiction of the fight for feminine suffrage draws on Hamilton's familiarity with the movement up to 1914 .

\begin{abstract}
[William and Griselda] had lived for so long less as individuals than as members of organisations (...). They believed that Society could be straightened and set right by the well-meaning efforts of well-meaning souls like themselves - aided by the Ballot, the Voice of the People, and Woman. They believed, in defiance of the teachings of history, that Democracy is another word for peace and goodwill towards men. They believed (quite rightly) in the purity of their own intentions; and concluded (quite wrongly) that the intentions of all persons who did not agree with them must therefore be evil and impure.... They were, in short, very honest and devout sectarians (...). (Hamilton, 1919, 19-20)
\end{abstract}

In the portrayal of two emotionally and politically immature characters, the writer deplores the dogmatism of some of her militant companions, their unawareness of the international situation, their smug certainties. 'Neither [in 1919] nor later could Hamilton abide the cruelty of herd mentality and the holier-than-thou dogmatism of organizational members - whatever the organization.' (Blodgett, 1990, 101).

However authentic in the devotion to their causes they may be, in the first two chapters everything about William and Griselda is diminutive.

Griselda Watkins, then a little under twenty-five, was [William's] exact counterpart in petticoats; a piece of blank-minded, suburban young-womanhood caught in the militant suffrage movement and enjoying herself therein. (...) Like William, she had no quarrel with continental nations; (...) her combatant instincts were concentrated on antagonists nearer home; (...) their little vision was as narrow as it was pure (...). (Hamilton, 1919, 16, 21, 22)

Their self-righteousness as the war draws near, 'the profound ignorance of the unread and unimaginative' (Hamilton, 1919, 29), contrasts with the reader's awareness that such bliss cannot possibly last.

Neither William nor Griselda had ever entertained the idea of a European War; it was not entertained by any of their friends or their pamphlets. Rumours of war they had always regarded as foolish and malicious inventions set afloat in the interests of Capitalism and Conservatism with the object of diverting attention from Social Reform or the settlement of the Woman Question; (...) their historical ignorance was so profound, they had talked so long and so often in terms of war, that they had come to look on the strife of nations as a glorified scuffle on the lines of a Pankhurst demonstration. (Hamilton, 1919, 74)

The reader's apprehension strengthens with the couple's choice for their three weeks' honeymoon at the end of July 1914 of an isolated idyllic 'cottage in the heart of the Belgian Ardennes'. (Hamilton, 1919, 31) In that secluded location no

\footnotetext{
${ }^{21}$ Spectator Archive, William — an Englishman. By Cicely Hamilton. 21 June 1919, Page 20. http://archive.spectator.co.uk/article/21st-june-1919/20/williaman-englishman-by-cicelyhamilton-skeffington. Accessed 08.03.2016.
} 
news from the outside world is obtainable. Neither of them is able to read, speak or understand French. Had they been more aware or better informed instead of deliberately 'shutting out sight and sound of the country peace, the oppressive peace in which they had no part'; (Hamilton, 1919, 45) they might have understood the ominous meaning of what they imagine is the sound of thunder. The narrator begins to favour a gentler tone.

If they had but known it, they were the last tourists of their race who for many and many a day to come were to look on the scene before them. Had they but known it, they would certainly have scanned it more keenly; as it was, they surveyed the wide landscape contentedly but with no particular enthusiasm. (Hamilton, 1919, 48)

They then misconstrue the sound of guns in the distance as military manoeuvres. Bored by 'the oppressive peace' of the countryside, lacking everyday militancy, they decide to leave for England. By then it is of course too late. The war they were too ignorant to expect is harshly upon them. Beaten, assaulted and taken prisoners by the Germans, William and Griselda obey the soldiers, 'in the clutch of brute force $(. .$.$) they trotted down the valley, humiliated, dishevelled, indignant, but still$ incredulous - while their world crumbled about them and Europe thundered and bled' (Hamilton, 1919, 75, 77).

The narrator now closely follows William's memories of his 'first acquaintance with the war as the soldier understands it' (Hamilton, 1919, 78), accompanying the couple's apprenticeship of suffering. Initial incredulity and shock soon give way to the revelation of hitherto inconceivable dimensions of brutality. The whole mood of the text is transformed to convey the pity and horror of war. And the reader's appalled awareness of this new reality follows William's transformation. Behind lies the 'gentle satire' first used to introduce the couple and acknowledged in Beauman's Preface (Beauman, 1999, ix).

With this novel Hamilton was taking leave of her own pre-war illusions.

(...) in depicting William's struggle to come to terms with the inadequacy of pacifism as a response to tyranny and his reluctant acceptance that there are campaigns more compelling than the fight for women's suffrage [Hamilton] offers some insights into the concerns which preoccupied her at this time (...). (Whitelaw, 1990, 164)

The reader shares William's distress as increasingly bleaker incidents follow one another.

For the first time mortal fear had seized him by the throat and shaken him. He knew now that he stood before death itself, and the power to inflict death (...). [t] he spasm of terror in those first moments of comprehension had been stronger than the spasm of pity (...). Long beating seconds (three or four of them at most) while two men stood upright with bandaged eyes and rifles pointed at their hearts; (...) The man with the grizzled hair threw out an arm and toppled with his face in the dust; the mayor slid sideways against the wall with the blood dribbling from his mouth. (Hamilton, 1919, 86-88)

Leaving behind well-meaning fantasies of internationalism, the ruthless execution of the village mayor constitutes William's initiatory rite of passage, his first epiphany of war and suffering, demoralizing any innocent pacifist ideals, 
to his pity and physical nausea was added the impotent, gasping confusion of the man whose faith has been uprooted, who is face to face with the incredible (...). War was: men were shot against walls. (Hamilton, 1919, 89-90)

The episode was based on Hamilton's knowledge of the barbarous treatment of Senlis, pitilessly occupied for a week, methodically burned, one street after another, and of the Germans' summary execution of its mayor. ${ }^{22}$ Summing up Hamilton's 1917 account, Whitelaw relates the fate of the town:

When the Germans marched into [Senlis], believing they had driven out the French soldiers, they were surprised to encounter pockets of resistance. (...) Wherever they encountered enemy fire they sent groups of French civilians taken at random from among the population ahead of them as they advanced towards the French guns. In some cases the French soldiers realised in time what was happening and held their fire but in others the civilians were shot by their fellow countrymen. (Whitelaw, 1990, 149)

The biographer emphasizes how such behaviour showed the author 'the totality of modern warfare; warfare in which soldiers could cold-bloodedly use civilians, including women and children, as stalking-horses; warfare in which there were no longer any rules.' (Whitelaw, 1990, 149).

The novel's pace is now intimately woven with the young man's responsiveness to what is happening around him. In the chaos of war the only order available is the chronology of event after event.

[T]he collision between William and Griselda's pastoral honeymoon and the brutalizing forces of the German army precipitates modernity's signature crisis: a rupturing of smooth historical time that defamiliarizes the present and reorders the past. (Seshagiri, 2013, 264)

The text's writing style now replicates William's suffering. Intense powerful images replace the understated prose of the first six chapters. Exhausted by forced labour, 'stupefied by pain and weariness' (Hamilton, 1919, 104), he witnesses a battle, is nearly caught by shellfire, helps a dying German boy-soldier.

\begin{abstract}
It was twisted now into a grin of agony, but all the same he recognized the face of the German boy-soldier who had dealt kindly with him that afternoon (...) lying on his back and covered from the middle downwards with a litter of broken beam and ironwork (...). The effect of recognition on William was curiously and instantly sobering; he was no longer alone in the hell where the ground reeled and men ran from him; he was no longer an animal wild and unreasoning, but a man with a definite human relationship to the boy lying broken at his feet. (Hamilton, 1919, 105-106)
\end{abstract}

The strange meeting and the horror of the whole situation are instrumental to William's transformation. Learning what real suffering may be, the impact of physical and psychological distress will change a little somewhat foolish (every)man into someone determined to fight the barbarity he experiences, 'the guns for the moment were a private persecution of himself, and he was conscious only of being foully and brutally bullied by monstrous forces with whom he argued and at whom he cursed and spat.' (Hamilton, 1919, 107).

${ }^{22}$ See Senlis, 38-39, 41, 45-46. 
The temporary disorder of his captors enables William to look for his wife in the deserted village. He finds her. In an empty little house Griselda is alone, '(...) crouched in a corner with her head on her knees, she neither saw nor heard him. (...) her face (...) white and tear-marked, with swollen lips and red eyes' (Hamilton, 1919, 113-114).

This is William's second and crucial epiphany. Griselda has been assaulted and abused.

For a moment he fought with the certainty, and then it came down on him like a storm: for once in his life his imagination was vivid, (...). All the details, the animal details, her cries and her pitiful wrestlings; the phrase 'licentious soldiering' personified in the face of the man who had been Griselda's gaoler. (Hamilton, 1919, 115)

In the debris of these two common diminutive lives the reader discovers a metonymy for the predicament of millions of ordinary persons trapped in war. 'Cicely's abhorrence of what she had seen during her time in France is channelled into her compassionate account of human suffering.' (Whitelaw, 1990, 162). The devastation she witnessed reverberates on the whole optimistic ethos.

The effect of the rape on Griselda's mind signifies the larger effect of the war on the discourse of suffrage and social reform; what had been whole and meaningful now shatters into a [sic] Eliotic heap of broken images. (Seshagiri, 2013, 265)

The protagonist understands that his own private agony is yet another materialization of the public catastrophe. The texture of people's lives in the everyday reality of war forces him to face up to the calamitous scale of the tragedy. Fleeing south with some Belgian refugees, his broken Griselda soon dies and is buried 'wrapped in a sheet'. (Hamilton, 1919, 145) William, compassionately helped, escapes to Paris and, 'seeing himself rather as an avenger of Griselda than as a soldier of the British Empire' (Hamilton, 1919, 162), learns to recognize his need for revenge. The former pacifist has become pro-war.

What he lacked in patriotism he made up in personal suffering; he hated the German because he had been robbed of his wife, (...). It was his persistent poring over English newspapers that brought him in the end the salvation of a definite purpose. (Hamilton, $1919,160)^{23}$

William's earlier militant certainties collapse, 'his new creed had at least this merit - it was supported by his own experience.' (Hamilton, 1919, 162-163)

Back in London, he tries to enlist but is rejected because of his frail physique. Hamilton's 1917 poem comes to mind. ${ }^{24}$

\footnotetext{
${ }^{23} \mathrm{See}$ also 'It was because of the horror inspired by [German sins] that they counted in a military sense. They stirred the loathing even of the unimaginative; they disposed once for all of the pacifist argument, "What if the Germans did come; we should not be any worse off". They made it impossible to suffer the victory of a nation that countenanced such sins.' (Senlis, 1917, 37).

${ }^{24}$ See this chapter pages $3-4$.
} 
Humiliated by enforced passivity, estranged from former acquaintances, he confronts them with his traumatic experience. The companions of a more innocent time are forced to hear a plain-spoken testimony.

\begin{abstract}
'You stand there and dare to make jokes about the hell that other men have burned in. The flames and the blood and the guns and people dying in the road. (...). Not one of you here has seen what I have - you're just guessing. When a shell bursts...I've seen a man with his legs like red jelly and a horse...' (...) Of course it shouldn't happen - we all know that - of course it shouldn't happen, but it does. And you can't stop it with sneers about soldiers and Kitchener....It's hell and the mouth of hell - I've seen it.' (Hamilton, 1919, 182-183)
\end{abstract}

Hamilton voices through William Tully her strong critical attitude towards those who insisted on ignoring the reality of war. Defending participation in the war effort as politically judicious and morally imperative, she wants to contribute to the collapse of distinctions between combatants and non-combatants.

William's 'sense of the impossibility of his previous classification of mankind into the well-intentioned and the evil' (Hamilton, 1919, 190-191) expresses Hamilton's own distance from her pre-war militancy. 'The war led Hamilton to believe firmly in the aggression of human nature.' (Frayn, 2014, 87) Her critique of social reformers, internationalist, pacifist and suffragist societies is an indictment of their and some of her own earlier convictions. First and foremost it is a wakeup call to those on the Home front. The Great War made a mockery of former certainties. Its viciousness forbade sentimentality and utopian delusions.

After having tried to enlist yet a third time, William Tully had surprisingly passed a medical inspection. Accepted in the army he collapsed after some weeks of drill. When 'out of the hospital (...) he was put on clerical duties. (...) handled a typewriter instead of a bayonet, and handled it steadily as the months lengthened into years.' (Hamilton, 1919, 198) This protagonist was never meant to be a hero. In her main character Hamilton put to good use her extensive knowledge of the administrative aspects of war. She was familiarized with the drudgery of wartime bureaucracy, its octopus like paper trail, the allegedly feminine qualities needed to endure it. Such activities further reinforce William's frustration.

His conception of soldiering, derived as it was from his own brief and fiery experience in Belgium, from the descriptive articles of war correspondents and his reading of bygone campaigns, had never included the soldier who was merely a clerk. (Hamilton, 1919, 198)

In August 1916 William is sent to France on clerical duties, 'a life of bleak order and meticulous, safe regularity, poles apart from his civilian forecast of the doings of a man of war.' (Hamilton, 1919, 204) The character suffers from his irrelevance.

William's pre-war beliefs and experience of the war mean that he is fuelled by bitterness. Even when the physical requirements have been lowered far enough for the diminutive William to enlist, he finds himself unsuited to commit violence and forced to revert to administration. (...) He still seeks individual action and agency, and refuses the notion of contributing to the war effort as significant. (...) Hamilton's novel demonstrates clearly the difficulties of reconciling pre-war enchantments with the realities of post-war Britain. (Frayn, 2014, 88-89)

As common and insignificant as ever, an air-raid will release him. 
Once it had seemed to him an easy thing to follow Griselda and die; now all the moral strength he possessed went into the effort not to shrink, to be master of his body, to behave decently and endure. That was all that seemed to matter - to be steady and behave decently - so that, for all his fear of instant death, he never turned his thoughts to God.... (Hamilton, 1919, 221-222)

One of the victims of the bombardment, he dies a quiet dignified death. His life had long lost all meaning and purpose. William, an Englishman, had felt a nobody not everyman. He could not imagine a future and revenge was not the answer.

William, an Englishman charts the young man's progress from initial naïve pacifism to trauma, recognition of bellicose patriotism and shattered final disappointment. In his all but anonymous life and death, William Tully represents millions of men (and women) whose lives were destroyed by the Great War.

\begin{abstract}
Hamilton's title character emerges as an overlooked exemplar of the damaged, ineffectual English masculinity that constitutes the subject of so much War-era modernism. Ford Madox Ford's Edward Ashburnham in The Good Soldier, D. H. Lawrence's Egbert in 'England, my England', Woolf's Jacob Flanders in Jacob's Room: William Tully shares with these frères et semblables a diminishing capacity for self-actualization, an unspectacular death, and a bleak legacy (...). (Seshagiri, 2013, 266)
\end{abstract}

In A Very Great Profession: The Woman's Novel 1914-39, Beauman emphasizes in Hamilton's text 'the grandeur of the ordinary' (Beauman, 1983, 31) that will become identifiable in later novels about the war.

(...) everyone matters in his own way, (..) integrity is the important quality and (..) the little (...) clerk has his grandeur as much as the swashbuckling soldier. [It] shows the effect of the enormous, uncontrollable might of war upon the lives of the petty, the unimportant and the ordinary. (Beauman, 1983, 31)

The main character and the whole novel signal the rupture between the pre-war meliorism that Cicely Hamilton had firmly professed and a new disenchanted awareness. Torn between the unequivocal need for social and political change and her experience of the physical and moral devastation of war, the scepticism that any radical transformation may indeed be achieved compels Hamilton to alert the reader. The text's denunciation of social progress, pacifism, internationalism as naive ideals may appear unexpected. 'William - An Englishman demonstrates how the vast scale of modern international warfare devastates even the most morally unquestionable revolutionary discourse.' (Seshagiri, 2013, 267).

Hamilton drew from personal knowledge and contemporary documents to write a novel that, while unquestionably touched by sympathy for her characters, is highly critical of their pre-war beliefs and activities. The text condemns the brutal futility of war and the vulnerability of civilian populations exposed to its ravages. William's words could be her own.

He hated the war as it affected himself, was weary of the war in general; all he longed for was its ending, (...) but neither hatred nor weariness had blinded his eyes to the folly of that other blindness which had denied that war could be (Hamilton, 1919, 216). 
The collapse of Hamilton's previous political optimism, her (self-ironical) criticism of any belief in the perfectibility of human beings may come as a shock even today. But, as was apparent at the beginning of this chapter, those familiar with her 1917 homage to Senlis might have anticipated Hamilton's sombre 1919 novel and the death she chose for William. The unprecedented power of aerial warfare, its ominous capacity to magnify the worst of once dreaded war experiences, the likelihood of further indiscriminate air strikes against both combatants and civilian populations, were 'in a flash' recognized by Hamilton as introducing a new (near) apocalyptic era. The bombardment of English coastal towns very early in the conflict had been a dismal warning.

Not only did Cicely Hamilton survive air-raids in France, she understood early on the brutal impact of the war from the air, the helplessness of cities, the persistent menace to both civilians and the military of this then recent weapon.

\begin{abstract}
The 'unfit' who step into the shoes of the fit, the old men who fill the gaps left by their sons, the women who press into fields and workshops - all these keep the fighting line going, and without them the fighting line must fail; and hence, under modern conditions of war, an increasing difficulty in drawing the line that protects the civilian from open attack by the soldier. A munition factory staffed by women, a laboratory where some weakling discovers a chemical compound, may be deadlier instruments of death and destruction than thousands of horses and men. Further, where each party to the strife enlists the services of his entire population (...) the question of national exhaustion looms far larger than it did in the day of the professional soldier and the army running to thousands. (Hamilton, 1917a, b, 35-36)
\end{abstract}

This was total war. The distinction between non-combatants and soldiers had lost its former meaning. Everybody became involved. Everybody became a target. Hamilton observed the dislocation of former hopes and heralded the fracture of long-cherished beliefs.

\begin{abstract}
The work and resources of a civilian population have always been an indirect factor in every military situation; but to-day they are a factor direct and declared, to-day the exempt and the women are openly mobilized and enlisted. One sees that this direct intervention of the civilian in warfare must entail a certain loss of his immunity from direct attack and punishment, and that a leader hard pressed or unscrupulous may deem himself entitled to interpret the fundamental maxim enjoining him to cut his enemy's communications in a fashion undreamed by those who framed rules for a conflict confined to the soldier. (...) The German leaders decided at the outset that their war was a war on non-combatants. (Hamilton, 1917a, 35-36)
\end{abstract}

However, Cicely Hamilton never gave up on her fight for a better world. In Tense Future: Modernism, Total War, Encyclopaedic Form, Saint-Amour reminds us, that 'like [Virginia] Woolf, Hamilton saw the future's apparent foreclosure as reason not for quietism but for intensified dissent.' (Saint-Amour, 2015, Loc. 3119) After the war she was involved in encouraging international women's suffrage, beginning the decade as press secretary for the Geneva Conference (1920) of the International Woman Suffrage Alliance. Throughout the 1920s she was lobbying for free birth control and abortion law reform. She continued to write and contributed regularly to Time and Tide, the first declaredly feminist newspaper, 'owned, managed and written entirely by women' (Whitelaw, 1990, 184). Hamilton 
never renounced her conviction that women's independence and equality of the sexes would ultimately ensure a better world for both women and men. ${ }^{25}$ In the early 1930s she endorsed the organisation of the Dignity in Dying. In 1940 Lament for Democracy denounced Nazism, Fascism and Bolshevism. A member of the Chelsea Fire Service during the Second World War, Hamilton in the 1930s and 1940s also published ten travelogues of her journeys to divers European countries. In her final years, from 1945 to 1952 , she was editor of the press bulletin of the British League for European Freedom. 'Hamilton did remain, movingly, awake and at work.' (Saint-Amour, 2015, Loc. 3645).

Cicely Hamilton's first-hand experience of the war, expressed in William, an Englishman, helped bridge the gap between civilians at home and those who had been in or near the front. Lessening the distance between them, the novel addresses and challenges what was too often and for too long a divided culture.

A sad, somewhat nostalgic adieu to the illusions she had cherished before the Great War, this novel is also a sad powerful warning of times to come. But the resilience she had witnessed in France might well have been the motto of her life, 'a joy and an encouragement, a reminder that life was lived peaceably once and may be lived peaceably again.' (Hamilton, 1918, 579).

\section{References}

Barratt, B. A. (2006). Cicely Hamilton. In B. A. Cook (Ed.), Women and war, an historical encyclopaedia from antiquity to the present (Vol. 1, pp. 273-274). Santa Barbara: ABC Clio. https://books.google.pt/books?id=lyZYS_GxglIC\&pg=PA273\&lpg=PA273\&dq=cicely+ hamilton+autobiography\&source $=$ bl\&ots $=$ jjkM2CkEZs\&sig=hbC18keop_nIgWFSqZEDGoS $5 \mathrm{GPU} \& \mathrm{hl}=\mathrm{en} \& \mathrm{sa}=\mathrm{X} \& \mathrm{ei}=\mathrm{rwdWVa} 1 \mathrm{Hxq} 1 \mathrm{RtdSBoAI} \&$ redir_esc $=\mathrm{y} \# \mathrm{v}=$ onepage $\& \mathrm{q}=$ cicely $\% 20$ hamilton\%20autobiography\&f=true. Accessed September 14, 2015.

Beauman, N. (1983). A very great profession: The Woman's Novel 1914-39. London: Virago.

Beauman, N. (1999). Preface to William, an Englishman (pp. v-xii). London: Persephone Books. Blodgett, H. (1990). Cicely Hamilton, Independent Feminist. Frontiers: A Journal of Women Studies, University of Nebraska Press, 11(2/3), 99-104.

Bowen, C. (2010). W.A.A.C's crossing the line in the Great War. Miranda [Online], 2. http:// miranda.revues.org/1102. Accessed March 17, 2016.

Brown, S., Clements, P., \& Grundy, I. (Eds.). (2006). Cicely Hamilton entry: Overview screen within Orlando: Women's writing in the British Isles from the beginnings to the present. Cambridge: Cambridge University Press Online. http://orlando.cambridge.org/. Accessed March 17, 2016.

Buck, C. (2005). British Women's Writing of the Great War. In V. Sherry (Ed.), The Cambridge Companion to the Literature of the First World War (pp. 85-112). Cambridge: Cambridge University Press.

Crofton, E. (2013). Angels of Mercy: A Women's Hospital on the Western Front 1914-1918 Foreword by Tam Dalyell, Edinburgh: eBook edition Birlinn Limited, 2013, Location 1177

${ }^{25}$ Cf. Kent, Susan Kingsley, 'The Politics of Sexual Difference: World War I and the Demise of British Feminism', 1988, 232-253. 
(originally published as The Women of Royaumont, A Scottish Women's Hospital at The Western Front, East Linton: Tuckwell Press, 1997).

Fernald, A. (2013, Summer). Women's fiction, New modernist studies, and Feminism. Modern Fiction Studies, 59(2), 229-240.

Frayn, A. (2014). Writing disenchantment: British First World War Prose, 1914-1930. Manchester: Manchester UP.

Fussell, P. (1975). The Great War and Modern Memory. New York: Oxford University Press.

Gregory, A. (2008). The Last War: British Society and the First World War. Cambridge: Cambridge University Press, 2014.

Hamilton, C. (1909). Marriage as a trade (Kindle edition). New York: Moffat, Yard and Company.

Hamilton, C. (1917a). Senlis. London: W. Collins Sons \& Co. LTD. https://archive.org/stream/ senlissenlis00hamirich\#page/124/mode/2up. Accessed June 23, 2015

Hamilton, C. (1917b). Non-combatant. The Westminster Gazette. www.inspirationalstories.com/ poems/non-combatant-cicely-hamilton-poems/. Accessed September 27, 2015

Hamilton, C. (1918, Oct.). Bombarded. The North American Review, 208(755), 574-581. University of Northern Iowa. http://www.jstor.org/stable/25122045. Accessed September 14, 2015 and September 27, 2015

Hamilton, C. (1922). Theodore savage: A Story of the Past or the Future. London: Leonard Parsons.

Hamilton, C. (1935). Life Errant, with twenty-two illustrations. London: J.M. Dent \& Sons. http:// fantastic-writers-and-the-great-war.com/war-experiences/cicely-hamilton/. Accessed September 22, 2015. http://ucblibraries.colorado.edu/archives/guides/wilpf.pdf. Accessed March 21, 2016.

Hamilton, C. (1999 (1919)). William, an Englishman. London: Persephone Books.

Hanley, L., (1991). Writing War: Fiction, Gender and Memory. Amherst: The University of Massachusetts Press.

Hermann, M. (2015). A History of Fear: British Apocalyptic Fiction, 1895-2011, foreword by Adam Roberts. Berlin: ePubli.

Hilson, M. (2006). Women voters and the rhetoric of patriotism in the British general election of 1918 \#1\#. Women's History Review, 10(2), 325-347, doi:10.1080/09612020100200284. Accessed March 21, 2016.

Hobsbawm, E. (1994). Age of Extremes: The Short Twentieth Century. London: Michael Joseph. Hoggart, L. (1998). The campaign for birth control in Britain in the 1920s. In A. Digby \& J. Stewart (Eds.), Gender, Health and Welfare. New York: Routledge. https://www.questia. $\mathrm{com} / \mathrm{read} / 103838231 /$ gender-health-and-welfare. Accessed September 21, 2015.

Kennedy, D. 'Cicely Hamilton's Twentieth Century', a paper delivered to the Belfast Literary Society, 3 April 2000. http://www.denniskennedy.eu/cicely.htm. Accessed September 21, 2015.

Kent, S. K. (1988, July). The politics of sexual difference: World War I and the Demise of British Feminism. Journal of British Studies, 27(3), The Dilemmas of Democratic Politics, 232-253. http://www.jstor.org/stable/175664. Accessed September 21, 2015.

Macaulay, R. (1986 (1916)). Non-combatants and others. London: Methuen.

Noveck, L. Cicely Hamilton: actress, playwright, journalist, feminist, suffragist. http:// onhershoulders.weebly.com/uploads/1/0/1/2/10121627/__on_her_shoulders_diana_of_dobsons_ program.pdf. Accessed September 24, 2015.

Peniston-Bird, C., \& Ugolini, W. (2015, February). Introduction to 'Silenced Mourning' [Special issue]. Journal of War \& Culture Studies, 8(1), 1-6. doi:10.1179/1752627214Z.00000000057. Accessed March 21, 2016.

Prix Femina. http://discovery.nationalarchives.gov.uk/details/rd/a77f8754-6b14-448c-a06fa491a43387f5. Accessed September 27, 2015.

Saint-Amour, P. K. (2015). Tense Future: Modernism, Total War, Encyclopaedic Form (Kindle edition). Oxford: Oxford University Press.

Seshagiri, U. (2013, Summer). Making it new: Persephone books and the modernist project. Modern Fiction Studies, 59(2), 241-287. 
Sherry, V. (Ed.). (2005). The Cambridge Companion to the Literature of the First World War. Cambridge: Cambridge University Press.

Sinclair, M. (1915). A Journal of Impressions in Belgium. New York: The Macmillan Company. https://www.gutenberg.org/files/31332/31332-h/31332-h.htm. Accessed March 07, 2016.

Spectator Archive. William-An Englishman. By Cicely Hamilton. 21 June 1919, 20. http:// archive.spectator.co.uk/article/21st-june-1919/20/williaman-englishman-by-cicely-hamiltonskeffington. Accessed March 08, 2016.

Stetz, M. D. (1991, Autumn). The life and rebellious times of Cicely Hamilton: Actress, writer, suffragist. [Review of the book Lis Whitelaw], Tulsa Women's Studies in Women's Literature, $10(2), 307-309$.

Tylee, C. M. (1990). The Great War and Women's Consciousness, Images of Militarism and Womanhood in Women's Writings, 1914-64. London: Macmillan.

Whitelaw, L. (1990). Life and rebellious times of Cicely Hamilton: Actress, wife, suffragist. London: The Women's Press. 